\title{
Viljan maailmanmarkkinahintojen vaihteluun vaikuttavat tekijät
}

Sanna-Helena Rantala, Helsingin yliopisto Taloustieteen laitos, Koetilantie 7 (PL 28) 00014 Helsingin yliopisto,sanna.rantala@helsinki.fi

\section{TIIVISTELMÄ}

Tutkimukseni käsittelee maailman viljamarkkinoiden hintavaihtelua ja hintaan vaikuttavia tekijöitä. Vuodesta 2003 lähtien maataloustuotteiden maailmanmarkkinahinnat ovat nousseet merkittävästi. Hinnat kohosivat huomattavasti vuosina 2007 ja 2008 ja varsinkin niin kutsuttujen päätuotteiden, eli vehnän, riisin, soijan ja maissin, hinnat nousivat radikaalisti. Suuresta hintavaihtelusta ja -noususta on käytetty jopa nimeä ruokakriisi.

Tutkimuksessani tarkastelen erityisesti vehnän maailmanmarkkinahintaa ja tutkin, mitkä tekijät ovat vaikuttaneet hintaan niin lyhyellä kuin pidemmälläkin aikavälillä. Näihin kysymyksiin vastataan ajankohtaisen kirjallisuuden ja empiirisen mallintamisen pohjalta. Tutkimuksen teoreettinen viitekehys perustuu hintateoriaan ja empiirisenä tutkimusmenetelmänä käytetään ekonometristä regressioanalyysiä. Tutkimuksen tarkoituksena on myös selventää empiirisesti nk. ruokakriisiin johtaneita tekijöitä.

Tutkimuksessa rakennetuilla yksinkertaisia ekonometrisia malleilla voidaan kuvata vehnän hintavaihteluita. Mallit on rakennettu kirjallisuudessa esitettyjen ruokakriisin aiheuttaneiden tekijöiden perusteella. Tutkimuksessa estimoitiin vehnän maailmanmarkkinahinnan kehitys sekä vuosina 1998-2009 että pidemmällä aikavälillä vuosina 1971-2008. Lyhyellä aikavälillä, 1998-2009, vehnän hintaa selittäviksi tekijöiksi valittiin vehnävarastojen tase, öljyn hinta, euron ja dollarin suhde, pitkien non commercial -positioiden määrä ja bioetanolin tuotannon määrä. Pidemmän aikavälin, 1971-2008, estimoinnissa vehnän hintaa selittävinä muuttujina olivat vehnävarastojen tase, öljyn hinta ja euron ja dollarin suhde.

Vehnän hintaa lyhyellä aikavälillä kuvaavan log-lineaarisen mallin selittävistä muuttujista varastojen tase, euron ja dollarin suhde, pitkien non commercial -positioiden sekä bioetanolin tuotannon määrä olivat vaikuttaneet vehnän hintaan vuosina 1998-2009 tilastollisesti merkitsevästi. Öljyn hinta ei ollut log-lineaarisessa mallissa tilastollisesti merkitsevä, vaikka aikaisemmassa kirjallisuudessa öljyn kohonnut hinta on usein esitetty syyksi ruuan hinnannousulle.

Vehnän hintaa estimoitiin myös pidemmällä aikavälillä, jolloin log-lineaarisen mallin selittävistä muuttujista tilastollisesti merkitseviä olivat öljyn hinta ja euron ja dollarin suhde. Vehnävarastojen tase ei ollut tilastollisesti merkitsevä pitkän aikavälin estimoinnissa.

Asiasanat: Vehnän maailmanmarkkinahinnat, ekonometrinen estimointi, ruokakriisi 


\section{Johdanto}

Tutkimukseni käsittelee viljan maailmanmarkkinahintojen vaihtelua ja siihen vaikuttaneita tekijöitä. Maataloustuotteiden hinnat kallistuivat merkittävästi vuosina 2007 ja 2008. Varsinkin niin kutsuttujen päätuotteiden, eli vehnän, riisin, soijan ja maissin, hinnat nousivat erittäin radikaalisti. (Baltzer ym. 2008.) Suuresta hintanoususta on käytetty jopa nimeä ruokakriisi. Monissa maissa kallistuneet maailmanmarkkinahinnat siirtyivät myös kuluttajahintoihin. (Trostle 2008).

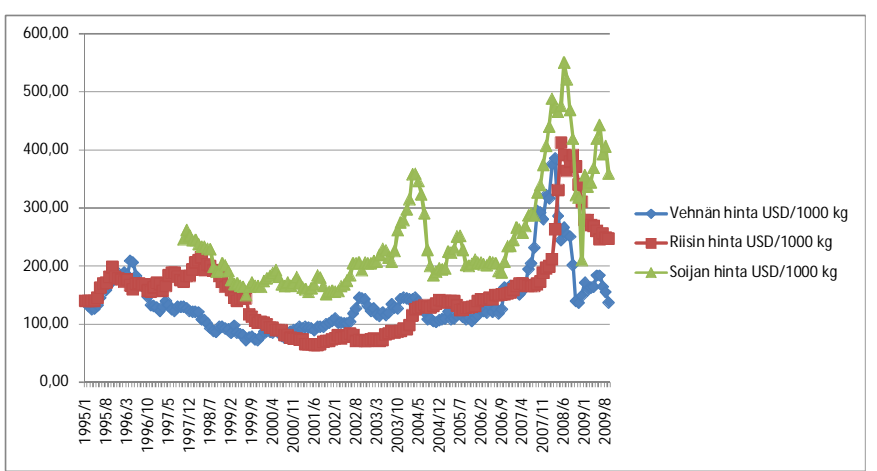

Kuva 1. Vehnän, riisin ja soijan maailmanmarkkinahinta vuosina 1995 - 2009 (USDA 1998-2009, USDA 2007, USDA 2009b, USDA 2009c)

Maataloustuotteiden hinnat vaihtelevat huomattavasti enemmän kuin monien muiden tuotteiden hinnat. Harvan tuotteen hinnat saattavat nousta $50 \%$ ja jälleen laskea useita prosentteja muutamassa kuukaudessa, kuten on maataloustuotteiden kohdalla. Tuotteiden hinnoissa voidaan kuitenkin huomata sekä satunnaista vaihtelua että systemaattisempaa käyttäytymistä. Maataloustuotteiden hintojen muodostuminen liittyy vahvasti tuotantoprosessin biologiseen luonteeseen. Luonnon olosuhteet, säät ja taudit sekä tuholaiset vaikuttavat tuotantoon merkittävästi verrattuna muihin aloihin. (Tomek ja Robinson 2003, s. 2-3.) Maailman viljamarkkinat ovat rakenteeltaan myös melko ohuet, sillä maailman viljantuotannosta maailmanmarkkinoille menee vain pieni osa. Suurin osa tuotetusta viljasta kulutetaan tuotantomaassa. Vehnän kokonaistuotannosta vain noin $17 \%$ menee maailmanmarkkinoille ja tuotetusta riisistä vain $7 \%$. Kun markkinat ovat näin ohuet, ne reagoivat helpommin globaaleihin kysynnän ja tarjonnan muutoksiin. (FAO 2008.)

Vuonna 2008 julkaistiin monissa kansainvälisissä maatalousekonomian lehdissä artikkeleita liittyen ruuan hinnannousuun ja niin kutsuttuun ruokakriisiin. Muun muassa Alexandratos (2008), Baltzer ym.(2008), Heady ja Fan (2008) ja Trostle (2008) käsittelivät ruokakriisiä ja sen syitä ja seurauksia artikkeleissaan. Agricultural Economics -lehti koosti syyskuussa 2008 oman liitteen pelkästään ruokakriisiä käsittelevistä artikkeleista. Yhdysvaltalainen Farm Foundation ja Abbott ym. koosti vuonna 200812 tutkimusta käyttäen apunaan laajan raportin ruuan hintakehityksestä. Raportti oli nimeltään "What's Driving Food Prices?".

Hinnannousun taustalla ei ole ollut vain yhtä tekijää. Jotkin tekijät ovat heijastaneet kysynnän ja tarjonnan muutoksia jo vuosikymmeniä sitten ja ennakoivat kysynnän ja tarjonnan suhteen merkittävää rakenteellista muutosta. Toisaalta on myös tekijöitä, jotka ovat ilmenneet vasta äskettäin ja niitä voidaan pitää hetkittäisinä shokkeina. (Trostle 2008.) Hinnannousun taustaltalla voidaan olettaa olevan ainakin seuraavat merkittävät tekijät 1) maailmanlaajuiset muutokset tärkeimpien tuotteiden tuotannossa ja kulutuksessa, 2) dollarin heikkeneminen suhteissa muihin valuuttoihin ja 3) biopolttoaineiden tuotannon ja kysynnän kasvu (Abbot 2008).

Heady ja Fan (2008) ovat laatineet mallin, jonka avulla voidaan selittää ruokakriisin tärkeimpien syiden ja tekijöiden keskinäisiä syy- ja seuraussuhteita. Mallista voidaan huomata, että tärkeimmät tekijät ovat juuri edellä mainitut USA:n dollarin heikkeneminen ja biopolttoaineiden tuotannon kasvu. Mallissa on mainittu myös keskeisenä tekijänä öljyn hinnan nousu Kaikki ruokakriisin syiksi mallissa luetut tekijät eivät vaikuta jokaiseen päätuotteeseen, sillä esimerkiksi vientirajoituksilla on ollut vaikutusta lähinnä vain riisin hintaan. Samoin Aasian kasvanut kysyntä vaikuttaa pitkälti öljykasvien hinnannousuun eikä niinkään esimerkiksi vehnän. Mallissa onkin esitetty heikommat ja tiettyyn tuotteeseen vaikuttavat tekijät katkoviivaisella laatikolla. Öljyn hinta ja 
Yhdysvaltain dollari ovat samassa laatikossa, sillä ne ovat yleismaailmallisempia muuttujia ja niiden välillä saattaa olla kausaalinen suhde.

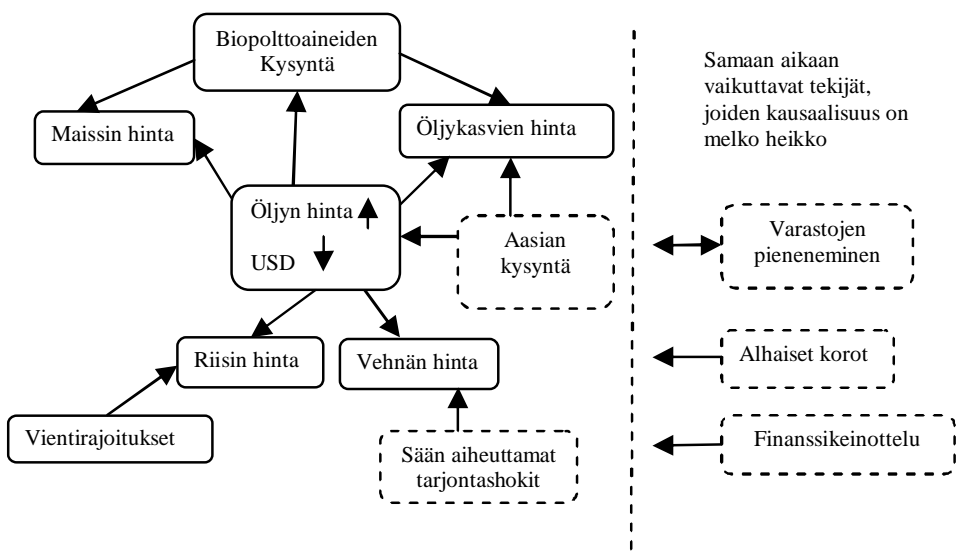

Kuva 2. Malli tärkeimmistä ruokakriisin syistä (Heady ja Fan 2008).

Tutkimuksessa selvitetään, mistä lähiaikojen hinnannousu (ns. ruokakriisi) johtuu ja mitkä asiat vaikuttavat erityisesti vehnän hintaan. Lisäksi tutkimuksessa tarkastellaan pidemmän aikavälin hintavaihtelua ja siihen vaikuttavia tekijöitä. Aihe on erittäin ajankohtainen ja tärkeä, sillä ruokakriisin vaikutukset ovat tuntuneet niin kehittyneissä maissa kuin varsinkin kehittyvissä maissa. Tutkimus on toteutettu yhteistyössä Maa- ja elintarviketalouden tutkimuskeskuksen kanssa.

\section{Aineisto ja menetelmät}

Tutkimusmenetelmänä käytetään ekonometrista analyysia. Tavoitteena on rakentaa ekonometrinen malli vehnän maailmanmarkkinahintaan vaikuttavista tekijöistä. Tutkimuksen ekonometrisen analyysin tekniikka on regressioanalyysi, jonka avulla voidaan selvittää selitettävän ja selittävän tai selittävien muuttujien välistä suhdetta (Ranta ym. 2002, 365). Tässä tutkimuksessa vehnän maailmanmarkkinahinta on selitettävä muuttuja ja siihen vaikuttavat tekijät ovat selittäviä muuttujia. Pienimmän neliösumman menetelmä on yleisin regressioanalyysin menetelmä. Menetelmässä etsitään sellaiset parametrien estimaatit, jotka minimoivat residuaalien neliösummaa. Mitä pienempi residuaalien neliösumma on, sitä parempi on estimoitu malli. (Gujarati 1995, 60-68.)

Vehnän hintaan vaikuttavia tekijöitä tarkastellaan aikajänteellä 1998-2009 ja 19712008. Tutkimuksen aineisto koostuu vehnän hinnan kuukausittaisista ja vuosittaisista aikasarjoista. Selitettävänä muuttujana on vehnän maailmanmarkkinahinta. Kansainvälisiä hintatilastoja viljojen osalta kokoaa Yhdysvaltain maatalousministeriön tilastopalvelu. (United States Department of Agriculture 2009a). Tarkasteltavat hinnat ovat nimellisiä.

Edellä on mainittu erilaisia syitä, jotka vaikuttivat ruuan hinnan nousuun viimeisimmässä ruokakriisissä. Vehnän osalta suurimpia syitä niin lyhyellä kuin pitkälläkin aikavälillä ovat olleet muun muassa säiden aiheuttamat tarjontashokit. Niiden aiheuttama vaikutus heijastuu varastojen taseessa, joten varastojen taseet on tarkasteltavan arvoinen muuttuja. Panoshintoihin vaikuttava öljyn hinta on oleellinen selittävä muuttuja samoin kuin euron ja dollarin suhteen kehitys. Kasvanut biopolttoaineiden kysyntä ja tuotanto varsinkin vehnän osalta ovat olleet syitä hinnan kohoamiselle, joten biopolttoiaineiden tuotanto on syytä ottaa mukaan tarkasteluun. Lähiaikoina maailman viljamarkkinoilla on lisääntynyt keinottelu hintafutuureilla ja sijoittajat ovat kiinnostuneet raaka-aineiden markkinoista (Heady ja Fan 2008). Selittävänä muuttujan mallissa onkin vehnän futuurikaupan "non commercial" -toimijoiden ostama pitkien positioiden määrä. Maailman kauppakomissiot määrittelevät viljojen hintafutuureilla kauppaa tekevät toimijat "commercial"- ja "non-commercial" -toimijoihin. Non commercial -kaupankävijät ovat toimijoita, jotka eivät ole perinteisiä viljafutuurikaupantekijöitä. Pitkän aikavälin estimoinnissa käytetään selittävinä muuttujina öljyn hintaa. varastoiden tasetta sekä euron ja dollarin suhdetta. Biopolttoaineiden ja futuurispekuloinnin merkitys hintojen kannalta on lisääntynyt vasta tällä vuosikymmenellä. 
Tässä tutkimuksessa tarkastellaan vehnän hintaa näiden selittävien muuttujien avulla ja tutkimuksessa onkin tavoitteena tutkia voiko yksinkertaisella pienimmän neliösumman menetelmällä tutkia kirjallisuudessa esitettyjen muuttujien merkitystä ruuan hinnalle.

\section{Tulokset ja tulosten tarkastelu}

Aluksi estimoitiin vehnän nominaalinen maailmanmarkkinahinta pienimmän neliösumman menetelmällä seuraavien parametrien avulla:

\section{Vehnän_hinta $=3,54921-0,0117504 *$ Varastojen_tase $+0,01549 *$ Öljyn-hinta - $\mathbf{0 , 5 8 8 2} *$ euro/dollari $+1,73152 \mathrm{e}-05 *$ NonComm_Positio + $\mathbf{0 , 0 1 4 3 0 8 4} *$ Biopolttoaineet}

Taulukko 1. Vehnän maailmanmarkkinahintaan vaikuttavia tekijöitä kuvaavan lineaarisen mallin arvot

\begin{tabular}{lrrrr} 
Selittävä tekijä & $\boldsymbol{\beta}$ & \multicolumn{1}{c}{ t-arvo } & p-arvo & Toleranssi \\
\hline Vakio & 3,55 & 2,66 & $0,009^{* * *}$ & \\
Varastojen tase & $-0,01$ & $-1,94$ & $0,054^{*}$ & 0,77 \\
Öljyn hinta & 0,02 & 2,25 & $0,026^{* *}$ & 0,18 \\
Euro/dollari & $-0,59$ & $-0,66$ & 0,508 & 0,39 \\
NonComm-positiot & $1,732 \mathrm{e}-05$ & 2,36 & $0,02^{* *}$ & 0,18 \\
Biopolttoaineiden tuotanto & 0,14 & 2,33 & $0,021^{* *}$ & 0,17
\end{tabular}

Muut mallia kuvaavat arvot:

$\mathrm{R}^{2}=0,698730$

F-testisuure $(5,127)=58,90974$

Durbin-Watson -testisuure $=0,25361$

Vapausasteilla korjattu. $\mathrm{R}^{2}=0,686869$

$\mathrm{P}-\operatorname{arvo}(\mathrm{F})=1,90 \mathrm{e}-31$

Taulukossa 1 on kuvattu lineaarisen mallin estimoinnin keskeiset tulokset, selitysasteet ja testit. Lisäksi kuviossa 3 on esitetty vehnän nimellisen maailmanmarkkinahinnan kehitys vuosina 19982009 ja maailmanmarkkinahintaa estimoiva malli.

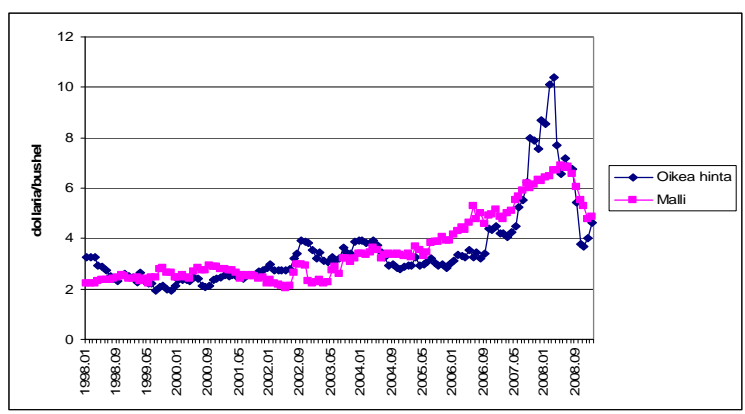

Kuva 3. Vehnän nimellisen maailmanmarkkinahinnan todellinen ja lineaarisella mallilla estimoitu hintakehitys vuosina 1998-2009.

Vehnän nominaalista maailmanmarkkinahintaa selittävän mallin selitysaste $\mathrm{R}^{2}$ on melko hyvä ja malliin sisällytettyjen muuttujien avulla voidaan selittää noin $70 \%$ vehnän maailmanmarkkinahinnasta. Yksittäisiä muuttujia tarkastellessa käy kuitenkin ilmi, että lukuun ottamatta vakiokerrointa, mikään muuttujista ei ole merkitsevä yhden prosentin riskitasolla. Suurin osa muuttujista on merkitseviä viiden prosentin riskitasolla. Dollarin ja euron suhde muuttujana ei ole merkitsevä kymmenenkään prosentin riskitasolla, joten voidaan todeta, että se ei selitä tilastollisesti merkitsevästi vehnän hintavaihtelua. Selittävien muuttujien etumerkkejä tarkasteltaessa voimme todeta niiden olevan loogisia ja aikaisempien tutkimusten mukaisia. Esimerkiksi kun öljyn hinta nousee yhden yksikön, nousee vehnän hinta 0,015 yksikköä.

Mallin selkeä heikkous ilmenee, kun tarkastellaan Durbin-Watson -testisuureen arvoa, 0,254. Arvo viittaa merkittävään positiiviseen autokorrelaatioon. Autokorrelaatiota voidaan vähentää 
hyödyntämällä Cochrane-Orcutt -tekniikkaa estimoinnissa. F-testisuureen perusteella malli selittää selitettävän muuttujan vaihtelua tilastollisesti merkitsevästi.

Multikollineaarisuutta testattiin toleranssin avulla. Tässä tapauksessa toleranssin arvot eivät alittaneet kriittistä arvoa 0,05 minkään muuttujan kohdalla, joten multikollineaarisuudesta ei ole haittaa. Heteroskedastisuutta testattiin Whiten testin avulla, joka osoitti, että mallin virhetermi on heteroskedastinen. Breusch-Godfrey -testin avulla selvitettiin myös mahdollinen autokorrelaatio. Testin tulokset viittasivat autokorrelaatioon.

Vehnän hintaa estimoitiin myös käyttäen log-lineaarista mallia ja havaitun autokorrelaation poistamiseksi Cochrane-Orcutt -tekniikkaa. Mallin parametreiksi saatiin:

\section{I_Vehnan_hinta $=1,66912-0,417316 *$ I_Varastojen_tase $+0,0904526 *$ I_Oljyn-hinta - 0,473222*I_euro/dollari + 0,0613749*1_NonComm_Positio + 0,143124*1_Biopolttoaineet}

Taulukko 2. Vehnän maailmanmarkkinahintaan (nominaalilihinnat) vaikuttavia tekijöitä kuvaavan loglineaarisen mallin arvot

Selittävä tekijä

Vakio

1_Varastojen_tase

1_Öljyn hinta

1_Euro/dollari

1_NonComm-positiot

1_Biopolttoaineet

$\mathrm{p}<0,10=* \mathrm{p}<0,05=* * \mathrm{p}<0,01=* * *$

$\mathrm{R}^{2}=0,953017$

$\mathrm{F}(5,126)=5,699016$

Durbin-Watson $=1,732718$

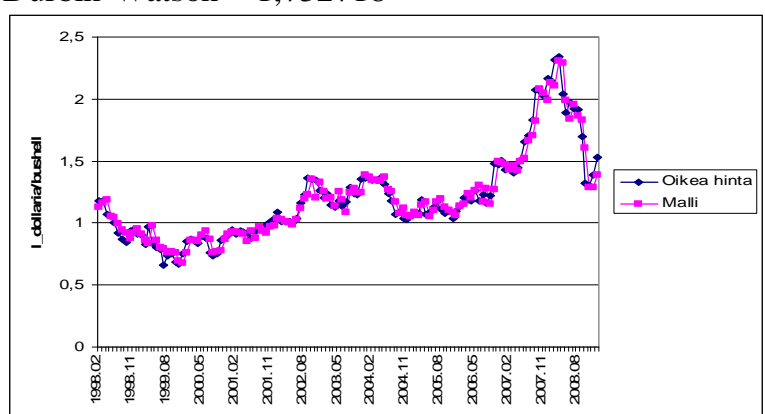

t-arvo p-arvo

$1,8950,0604 *$

$-2,7970,0060 * * *$

$1,326 \quad 0,1874$

$-1,6870,0941 *$

$1,8870,0615 *$

$1,8060,0733^{*}$

Vapausasteilla korjattu $\mathrm{R}^{2}=0,951152$

P-arvo $(\mathrm{F})=0,000090$

Kuvio 4. Vehnän maailmanmarkkinahinnan todellinen ja log-lineaarisella mallilla estimoitu hintakehitys vuosina 1998-2009. Cochrane-Orcutt -tekniikkaa on myös hyödynnetty estimoinnissa.

Muuttujista ainoastaan öljyn hinta ei ollut tilastollisesti juurikaan merkitsevä. Muut muuttujat olivat 1 $-10 \%$ riskitasolla tilastollisesti merkitseviä. Muuttujien etumerkit olivat myös pitkälti loogisia. Mallin selitysaste oli korkea, 0,95, ja Durbin-Watson -testisuure oli Cochrane-Orcutt tekniikan ansiosta melko hyvä 1,73.

Vehnän maailmanmarkkinahintaa pitkällä aikavälillä kuvaavan log-lineaarisen mallin parametrien arvoiksi saatiin:

I_Vehnan_hinta $=2,09029+0,227603 *$ I_Öljyn-hinta $-0,622293 * 1$ EUR_dollari $0,186737 * 1$ _Varastojen_tase 
Taulukko 3. Vehnän maailmanmarkkinahintaan vaikuttavia tekijöitä kuvaavan log-lineaarisen mallin arvot

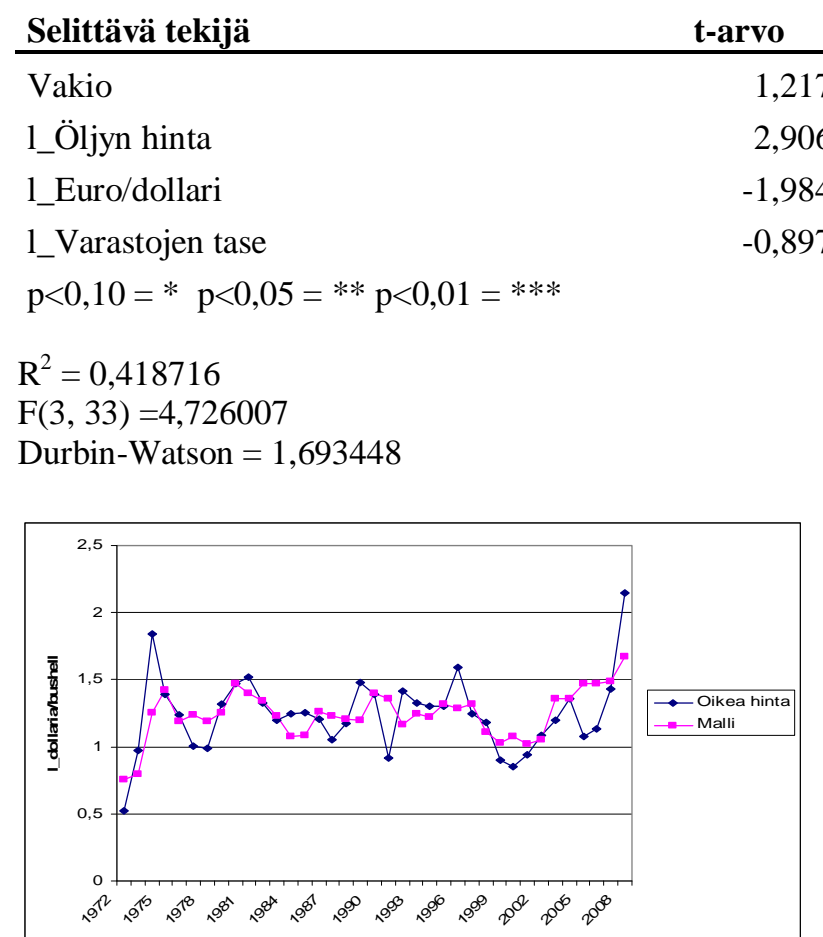

Kuva 5. Vehnän maailmanmarkkinahinnan todellinen ja log-lineaarisella mallilla estimoitu hintavaihtelu vuosina 1972-2008.

Cochrane-Orcutt -tekniikalla poistettiin positiivista autokorrelaatiota myös mallin kohdalla. Mallin selitysaste oli myös matala, vain 0,418716. Selittävistä muuttujista tilastollisesti merkitsevät olivat öljyn hinta ja euron ja dollarin suhde 1-10 \% riskitasolla. Varastojen tase -muuttuja ei ollut tilastollisesti merkitsevä.

\section{Johtopäätökset}

Tutkimuksessani estimoin vehnän maailmanmarkkinahinnan kehitystä sekä vuosina 1998-2009 että pidemmällä aikavälillä vuosina 1971-2008. Tutkimuksen tavoitteena oli rakentaa ekonometrisia malleja, joilla voidaan kuvata vehnän hintavaihteluita.

Tutkimuksen teoreettinen viitekehys perustui hintateoriaan ja tutkimuksessa tarkasteltiin myös vuosien 2007 ja 2008 maailmanlaajuista ruokakriisiä. Tutkimuksessani käsiteltiin erityisesti kirjallisuudessa esitettyjen ruokakriisin aiheuttaneiden syiden vaikutusta ruuan hintaan ja tätä tietoa hyödynnettiin erityisesti tutkimuksen empiirisessä osassa. Selittävät muuttujat on valittu ajankohtaisen ruokakriisiä käsittelevän kirjallisuuden avulla. Tutkimusmenetelmänä käytin ekonometrista estimointia ja aineisto estimoitiin klassisen pienimmän neliösumman menetelmällä.

Vehnän maailmanmarkkinahintaa estimoitiin sekä lineaarisen että log-lineaarisen mallin avulla. Autokorrelaation vähentämiseksi käytettiin Cochrane-Orcutt -tekniikka. Log-lineaarinen malli osoittautui hieman paremmaksi kuin lineaarinen malli, sillä sen muuttujista useampi oli tilastollisesti merkitsevä. Lisäksi log-lineaarisen mallin selitysaste oli korkeampi kuin lineaarisella mallilla. Log-lineaarinen malli selittää noin $95 \%$ vehnän hinnan vaihtelusta. Log-lineaarisen mallin mukaan vehnän maailmanmarkkinahintaa selittävät lyhyellä aikavälillä varastojen tase, euron ja dollarin suhde, non commercial pitkien positioiden määrä ja biopolttoaineiden tuotanto. Öljyn hinta ei ollut lyhyen aikavälin mallissa tilastollisesti merkitsevä, vaikka useassa kirjallisuuslähteessä on näin mainittu. Öljyn hinta vaikuttaa kuitenkin välillisesti muihin selittäviin muuttujiin, sillä se vaikuttaa tuotannon määrään ja sitä kautta varastoihinkin. Myös valuuttakurssit ja öljyn hinta vaikuttavat toisiinsa..

Pitkän aikavälin tarkastelussa log-lineaarinen malli selittää $45 \%$ vehnän hintavaihtelusta. Estimoinnissa hyödynnettiin myös Cochrane-Orcutt -teknikkaa autokorrelaation 
vähentämiseksi. Pitkällä aikavälillä vehnän hintaa selittävät tilastollisesti merkitsevästi öljyn hinta ja euron ja dollarin suhde. Varastojen tase ei ollut tilastollisesti merkitsevä pitkällä aikavälillä. Heady ja Fanin (2008) mukaan varastojen vaikutus maailmanmarkkinahintaan ei ole yksiselitteinen. Joskus varastojen tasoon vaikuttaa politiikka, jolloin sen vaikutus on suurempi ruuan hintaan. Varastojen määrään vaikuttaa kuitenkin monet muut ruuan hintaan vaikuttavat tekijät.

Kirjallisuudessa on esitetty useita syitä, jotka vaikuttavat vehnän ja riisin hintoihin ja julkinen ja tieteellinen keskustelu viljojen hintaan vaikuttavista tekijöistä lisääntyi merkittävästi viimeisimmän ruokakriisin aikana. Viljojen merkittävän hinnannousun syiksi on kuitenkin nähty monessa tutkimuksessa melko samanlaisia tekijöitä. Öljyn hinta, dollarin heikkeneminen, varastojen pieneneminen, huonot sadot, spekulaatio viljamarkkinoilla, biopolttoaineiden lisääntynyt kysyntä ja tuotanto sekä myös politiikka on nähty merkittävimpinä syinä ruuan hintanousuun.

Tutkimuksessani pyrittiinkin yksinkertaisella mallilla selvittämään sekä riisin että vehnän hintaan vaikuttavia tekijöitä. Tulokset antoivat empiirisiä viitteitä, että osa edellä mainituista tekijöistä on vaikuttanut vehnän ja riisin hintaan. Yksinkertaisen pienimmän neliösumman menetelmän käyttö näin laajan ongelman tutkimisessa ei ole täysin ongelmatonta, sillä esimerkiksi pienimmän neliösumman menetelmän oletukset eivät täyttyneet täysin ja monessa mallissa olikin havaittavissa heteroskedastisuutta ja autokorrelaatiota. Varsinkin epästationäärisyys aiheuttaa ongelmia tutkimuksessa ja viljojen hintoihin vaikuttavat varmasti myös monet muut tekijät, joita ei ole mallissa otettu huomioon. Tutkimukseni empiiriset tulokset ovat kuitenkin pääosin linjassa aikaisempien tutkimusten kanssa ja viittaavat siihen, että vehnän maailmanmarkkinahintoihin vaikuttavat varastojen taseet, öljyn hinta ja dollarin heikkeneminen. Myös lyhemmän aikavälin tekijöillä, kuten biopolttoaineiden kysynnän kasvulla ja viljafutuurien keinottelulla, on vaikutusta maailmanmarkkinahintoihin.

\section{Kirjallisuus}

Abbott, P. C., Hurt, C. \& Wallace, E. T. 2008. What's Driving Food Prices? Farm Foundation. Issue Report. 7/2008.

Alexandratos, N. 2008. Food Prices Surges: Possible Causes, Past Experience and Longer Term Relevance. Population and Development Review 34, 4: 663-697.

Baltzer, K., Hansen, H. \& Lind, K. M. 2008. A note on the causes and consequences of the rapidly increasing international food prices. Institute of food and resource economics. University of Copenhagen. May 2008.

Food and Agriculture Organization of the United Nations. 2008. Food Outlook, November 2008. Saatavilla: http://www.fao.org/docrep/011/ai474e/ai474e03.htm. Viitatu 24.2.2009.

Gujarati, D. N. 1995. Basic Econometrics - Third edition. McGraww-Hill International Editions Economic Series. Singapore. 838 p.

Heady, D. \& Fan, S. 2008. Anatomy of a crisis: the causes and consequences of surging food prices. Agricultural Economics, 39, 1: 375-391.

Ranta, E., Rita, H. \& Kouki, J. 2002. Biometria - Tilastotiedettä ekologeille. Yliopistopaino. Helsinki. Suomi. Tomek, W. G. \& Robinson, K. L. 2003. Agricultural Product Prices - fourth edition. Cornell University Press. USA. 428 p.

Trostle, R. 2008. Global Agricultural Supply and Demand: Factors Contributing to the Recent Increase in Food Commodity Prices. United States Department of Agriculture. A Report from the Economic Research Service. May 2008.

United States Department of Agriculture. 1999-2009. Oilseed: World Market and Trade Archives. Reports: 12-99, 12-00, 12-01, 12-02, 12-03, 12-04, 12-05, 12-06, 12-07, 10-09. Foreign Agricultural Service. Saatavilla: http://www.fas.usda.gov/oilseeds_arc.asp. Viitattu: 2.3.2009.

United States Department of Agriculture. 2007. Rice Yearbook 2007. Table 17 Adjusted world rice price, loan rate basis. Economic Research Service. Saatavilla: http://usda.mannlib.cornell.edu/MannUsda/viewDocumentInfo.do?documentID=1229. Viitattu: 2.3.2009.

United States Department of Agriculture. 2009a. Wheat data, yearbook table no. 2 soft red winter, Chicago Illinois. Economic Research Service. Saatavilla: http://www.ers.usda.gov/Data/Wheat/Yearbook/WheatYearbookTable19-Full.htm. Viitattu: 10.2.2009.

United States Department of Agriculture. 2009b. Briefing Rooms: Rice Outlook Monthly Tables. Table 5 USDA calculated world market rice prices (rough basis). Economic Research Service. Saatavilla: http://www.ers.usda.gov/Briefing/Rice/data.htm. Viitattu: 2.3.2009.

United States Department of Agriculture. 2009c. USDA-calculated world market rice prices (rough basis) long. Saatavilla: http://www.ers.usda.gov/Briefing/Rice/data.htm. Viitattu 10.2.2009. 